\title{
Theoretical Exploration and Path Construction of Ideological and Political Theories Teaching under the background of New Business Education
}

\author{
Yonghui $\mathrm{CAO}^{1, \mathrm{a}}$, He JIANG ${ }^{* 1, \mathrm{~b}}$ \\ ${ }^{1}$ Department of Business Administration Guangzhou College of Technology and Business Guangzhou, China
}

\begin{abstract}
In recent years, with the reform of higher education in various aspects, China's higher education is booming. The innovation of higher education, including ideological and political theories teaching and new business education, puts forward new requirements for China's universities. Therefore, it is of great theoretical and practical significance to study the theoretical development and construction path of courses for ideological and political education under the background of new business education. Based on this, this paper organically combines the new business education construction with the ideological and political curriculum, so as to provide theoretical support and theoretical thinking for the talent cultivation of the new business education.
\end{abstract}

\section{Introduction}

In recent years, with the reform of higher education in various aspects, China's higher education is booming. The innovation of higher education, including the ideological and political courses and the new business education subjects, puts forward new requirements for China's colleges and universities[1-2]. General Secretary Xi Jinping delivered an important speech at the National College Ideological and political work conference held in December 2016. He pointed out that "we should be integration of Ideological, Political Courses into all profession courses to form a synergy effect." This speech is an important statement by general secretary Xi Jinping on the relationship between all kinds of courses and ideological and political theory courses in universities. This has a far-reaching impact on the reform and development of China's higher education in the new era, and points out the direction for the ideological and political work in the education system. In recent years, the related research also presents a growing trend. As of February 27, 2021, CNKI has retrieved papers with the theme of "Ideological and political education of curriculum", and the retrieval year is set to 2010-2021. The source category of papers is set to Chinese core journals and CSSCI journals. The most papers are retrieved from 2019-2021. The retrieval situation is as follows: 32 papers are retrieved from 2021, 370 papers are retrieved from 2020, and 39 papers are retrieved from 2019. This shows that the research of Ideological and political courses has become a hot spot. Under this background, how to integrate the ideological and political courses with the development of disciplines in Colleges and universities is imperative[3].

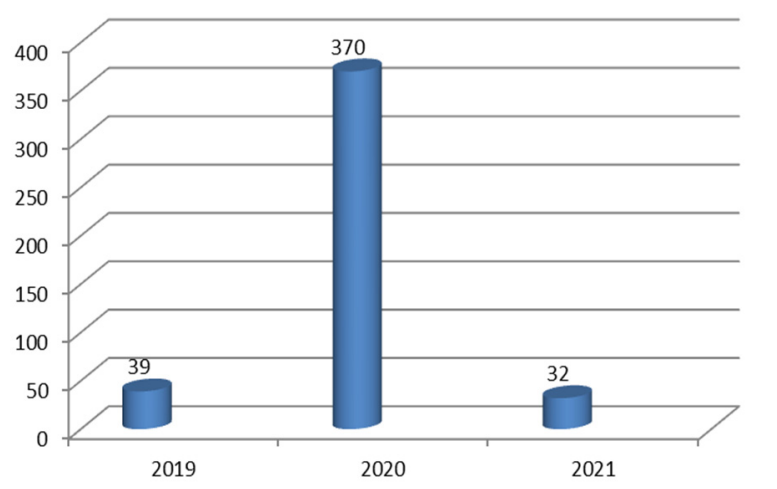

Figure 1 the trend of Chinese core and CSSCI papers retrieved from 2010 to 2021

In 2018, taking the opportunity of the national education conference, the work of new engineering, new arts, new agriculture, new medicine and international certification has been put on the agenda. These educational reforms have a positive impact on the development of China's education. The new business education is the most closely combined with economic development and market demand. In the context of the new era, it is more urgent, which also puts forward new requirements for the further development of business in Colleges and universities. At present, China's business service industry is developing rapidly, and some characteristics of the times also show the necessity of the transformation and development of business education, such as big data, cloud computing, sharing economy. It can even be said that it has entered the era of business 3.0. Some traditional business forms are being replaced by online e-commerce based on information technology, which calls for a new era of business higher education based on traditional business. Therefore, it is great 
theoretical and practical significance to study the theoretical development of curriculum ideological and Political Education under the background of new business education, and provide some basis and Countermeasures for colleges and universities to carry out ideological and political education.

\section{Theoretical exploration of Ideological and political education in the background of new business education}

\subsection{The theoretical development of "new business education"}

In the rapid change of the new era, innovation has become an eternal theme, and new business education should also be based on the actual situation. Combined with the new pattern of dual cycle development in China, based on the demand of supply side reform, we should carry out the new transformation of higher education promoted by market integration and enterprise. The development of cloud computing, big data and other new technologies is changing the way of thinking and working, especially for college students' curriculum system and training mode. To explore the development of new business education, especially the high-quality business talents in China under the background of complex economy, it is become the key for China to cope with the complex challenges of the world, enhance its international competitiveness, and achieve high-quality economic development. In all this, we must first correctly understand the nature and characteristics of business.

First, the new business education is business education in China. The new business education must embody the theories and methods with Chinese characteristics, which strive to build a management system with Chinese characteristics, and avoid the disadvantages of using western theories and cases in the previous business education. Combined with the development of China's economy, endless cases provide the original scene from China for the development of new business education, which can serve the actual needs of Chinese enterprises and economic development.

Second, new business education is a comprehensive discipline that fully integrates new technology. Compared with the function orientation of traditional business, the cultivation of new business education talents in higher education tends to integrate with modern new technologies, such as cloud computing and big data. Through the use of information technology, combined with the reality of social and economic needs, it focus on training interdisciplinary talents, so that the new business education talents can adapt to the actual needs of economic development, and can solve the complex problems in the actual business scene.

\subsection{The theoretical connotation of Ideological and Political Theories teaching in All Courses}

The proposal of "Ideological and Political Theories teaching in All Courses " is the most important idea of education and teaching reform in recent years, which is also a clear requirement for higher education in the new era. In the current education reform, college students' Ideological and moral and family feelings will be cultivated through the accurate positioning and collaborative innovation of Ideological and political courses, general courses and professional courses[4]. By playing the main channel function of classroom teaching, we can achieve the goal of whole curriculum education. In May 2020, the Ministry of Education issued the "guidelines for ideological and political construction of university curriculum", which clearly proposes to promote ideological and political construction of university curriculum, which is a strategic measure to implement the fundamental task of moral education. Combining with the background of the new curriculum reform, integrating the ideological and political education into the education reform is an important task to implement the trinity of value building, knowledge teaching and ability training in Colleges and universities[5].

\subsection{The necessity and urgency of Ideological and political education in the background of new business education}

"New business education" is to reorganize and cross the traditional business subjects, integrate new technology into business courses, and provide comprehensive interdisciplinary education for students with new ideas, new models and new methods. "New business education" is a new concept of economic management education under the concept of "new liberal arts" At present, China's rapid economic development, especially after the 2020 COVID-19, from the total amount of economic GDP, China is the world's few positive growth countries, to a certain extent, illustrates the effectiveness of our economic workers and business managers in the actual work. Therefore, further strengthening the business education and $\mathrm{t}$ ideological and political theories teaching will provide a sustainable guarantee for the cultivation of business talents in China, and the ideological and political construction of the new business curriculum is of great significance. At the same time, in the new era, with the rapid development of economy and the aggravation of global competition, how to cultivate both red and professional business talents is also an urgent problem to be solved in China's business higher education.

\section{The path construction of Ideological and political education in the background of new business education.}

\subsection{Give full play to teachers' principal position in curriculum ideological and Political Education}

In the teaching of new business subjects, teachers need to arrange all kinds of teaching resources to ensure the effective implementation of Ideological and political courses, which is also an important embodiment of 
teachers' subjectivity. In addition, in the classroom teaching of business course Ideological and political education, we can't weaken the value guidance of the course Ideological and political education by using the excuse of spreading knowledge and cultivating ability for students, and we can't reduce the study of professional theory by paying too much attention to the course Ideological and Political Education. The relationship between professional knowledge and ideological and political education needs teachers to effectively balance and achieve the goal of moral education through value guidance. Moreover, the selection and compilation of teaching materials is another embodiment of teachers' status as the main body of Ideological and political education. Nowadays, most of the teaching materials used in Colleges and universities are Marxist theoretical research and Construction Engineering (referred to as "Ma Engineering") teaching materials, and some of them are self-compiled teaching materials. However, no matter what kind of teaching materials, teachers need to carefully study the contents of the teaching materials and understand the ideas of the teaching materials, so that they can analyze the ideological and political education of the curriculum from the perspective of professional knowledge, organically integrate the curriculum syllabus and teaching plan, and closely integrate the professional knowledge and value guidance through the analysis of the key and difficult points, so as to achieve knowledge teaching, ability training and value orientation Leading the unity of threedimensional goals.

\subsection{Improving teachers' Ideological and political ability in the new business by training}

First, it can be strengthen the construction of teachers' ethics by training. Although curriculum ideological and political education focuses on the integration of professional knowledge and ideological and political education, as the guide of teaching, professional teachers' behavior can affect students' learning enthusiasm and moral feelings. Professional teachers' ethics is an important factor to build trust with students, so there is no doubt that the construction of teachers' ethics is a precondition for the effective implementation of curriculum ideological and political education. Through the training of new teachers, young teachers and backbone teachers, the external image and internal thought of new business teachers can be improved, so that teachers can truly become disseminators of socialist core values and reformers of curriculum ideological and political work.

Second, it could be strengthened teachers' awareness of Integrating Ideological and political elements into the teaching process by training. The new business is also the product of higher education reform, and the ideological and political construction of curriculum is also the education path that China's higher education pays special attention to in recent years. Therefore, in the training, teachers should make full use of the opportunity of teaching professional courses and consciously combine the relevant contents with the ideological and political construction. Only by internalizing this kind of consciousness into Teachers' professional consciousness, can we promote new business teachers' Ideological and political ability in all aspects, imperceptibly change it into their own professional quality, and also can we speak well about professional knowledge and curriculum ideological and political content.

Third, it could be improved teachers' ability to dig out ideological and political elements in professional knowledge by training. In the new business education, we smoothly complete the task of teaching reform of the new business and achieve the goal of education by skillfully combining the relevant professional knowledge with the ideological and political construction. Because some teachers lack the ability to excavate the ideological and political elements in their professional knowledge, they rigidly combine the professional knowledge with the moral elements, so that students could not fully understand the teacher's intention in the learning process, which leads to the lack of key and difficult knowledge of the course. Through increasing the training efforts and adopting various forms could be enlighten teachers' curriculum ideological and political ability, sustainable teaching ability can be formed. In the practical training, we can also use the new business professional course demonstration cases, combined with the teaching objectives and contents of the professional courses, to demonstrate the operation methods of integrating the ideological and political education content into the specific teaching links, so that the trained teachers can experience the process of the ideological and political reform of the course from the perspective of students, and truly understand the measures and methods of the ideological and political reform of the course.

\subsection{Carefully design of new business talent training program and curriculum system}

It should improve the new business curriculum ideological and political system. For the ideological and political construction of the new business curriculum, we must base on the professional characteristics and form an innovative ideological and political construction system of a certain specialty in the new business curriculum. At the same time, we should combine the school history, specialty setting, teachers' strength, etc., comprehensively utilize the existing resources and refine the cultural gene and value paradigm of the specialty. Through the establishment of reproducible experience with certain effect, the unity of knowledge teaching and value guidance can be realized. In addition, we should coordinate the ideological and political construction tendency of professional courses and avoid the repetition of Ideological and political content in the teaching process of different courses, so as to reduce the teaching effect. The key to solve this problem is to build a comprehensive three-dimensional framework of curriculum ideological and political education, form a complete collaborative education system of curriculum ideological and Political Education Department, and give full play to the role of comprehensive ideological and political education. 


\subsection{Improving the mechanism of Ideological and political education in the new business curriculum}

In order to make the new business curriculum ideological and political to achieve better results, we need to improve the entire education mechanism. Although professional teachers play an important role in curriculum teaching, it needs the joint efforts of all educators in the whole college and even the whole school. The school should create a good atmosphere, carry out the top-level design and overall arrangement of the ideological and political construction of the curriculum as a whole, and play the role of the overall designer. Colleges and departments are the important implementers and promoters of the ideological and political work of the curriculum. They need to make overall arrangements for the work of colleges, departments and teaching and research sections, give full play to the positive role of grass-roots units, and form a strong joint force of moral education. The person in charge of the major should take the corresponding responsibility, timely determine the ideological and political objectives of the major, formulate the corresponding professional ideological and political plan and organize the implementation. Every teacher should understand the significance and arrangement of the ideological and political construction of the school, department and teaching and research section of the major, and implement the ideological and political construction of each classroom. At the same time, we should play the role of teachers and students' Party branches, integrate the ideological and political construction inside and outside the classroom, and effectively improve the effect of Ideological and political construction.

\subsection{Implement the management and evaluation of the ideological and political process of the new business curriculum}

The ideological and political education construction should effectively implement the process management and feedback the ideological and political effect through the corresponding evaluation mechanism, and make timely adjustment in the process of new business talents training of the course. First of all, from the perspective of the overall process management, we should do a good job in the system construction of Ideological and political process management, and organize corresponding special activities in combination with the new business major, so as to implement the spirit of Ideological and political construction in each specific work. Secondly, from the specific classroom teaching process, the professional teachers of new business should design the content and time arrangement of the classroom, organically integrate the ideological and political content into the specific teaching of each class under the guidance of the talent training plan and curriculum outline, and timely summarize the problems in the teaching link after class, improve the teaching methods and methods, in order to improve the quality of new business professional courses. Finally, we should do a good job in the evaluation of the ideological and political construction of the new business curriculum. According to the systematic arrangement of process management, the scientific evaluation index is established. We can establish a regular and dynamic evaluation mechanism, such as a regular evaluation once every six months, summarize the achievements and problems in the ideological and political construction as a whole, and give timely feedback to the teachers of each department and teaching and research section. At the same time, we should also do a good job in the dynamic evaluation of the ideological and political construction of the new business curriculum, and make timely adjustments according to the new problems and new situations. In addition, for those who are outstanding in the course of Ideological and political education, we should do a good job in the corresponding reward work, set an example, and do a good job in the demonstration effect.

\section{Conclusion}

With the development of economy and the aggravation of competition, the demand for business talents becomes more urgent. In the process of new business education, how to integrate the content of Ideological and political education is of positive significance for the cultivation of business talents who can shoulder the responsibility of China's economic sustainable development. It is necessary for colleges and universities in China to carry out the ideological and political reform of the curriculum in combination with the characteristics of the new business major, continuously deepen the new business teachers' deep understanding of the ideological and political significance of the curriculum, and continuously strengthen the responsibility of teachers as the theme of Ideological and political education of the curriculum. Through the establishment of a perfect new business talent training program, we can set up a curriculum system suitable for the development of the times. From plan making to process management to final evaluation and improvement, we should fully tap the characteristics and advantages of business major, extract its cultural genes and value paradigm, and transform it into an effective teaching carrier with concrete and vivid socialist core values. Only in this way, can we cultivate all-round high-quality applied new business talents, so as to promote the high-quality development of China's economy.

\section{Acknowledgment}

This work is financially supported by "Four one" construction pilot project of Ideological and political course of Guangzhou College of Technology and Business in 2020(KCSZ202001); outstanding scholars of philosophy and Social Sciences in Henan Province higher education in 2018, 2018-YXXZ-06; Henan philosophy and Social Sciences Planning Project in 2019, 2019BJJ003; The social development project of Henan provincial key R \& D and promotion project (Science and technology tackling key problems) in 2019, project number: 515; Intellectual property soft science research project of Henan Province in 2021, 20210106014; Guangdong Education Science Planning Project, building an efficient and intelligent supply chain system to promote 
the high-quality economic development of GuangdongHong Kong-Macao Greater Bay Area, 2019GXJK072; Henan philosophy and Social Sciences Planning Project in 2019, 2019BJJ032; Key scientific and technological projects of Henan Province in 2021, 212102310051, Research on emergency decision-making mechanism and key technologies of major public emergencies; the key scientific research project of colleges and universities in Henan Province in 2021, 21A620002; General Topics of Henan Province Educational Science "13th Five-Year Plan" in 2020, Research on the dynamic mechanism of the integration of industry and education in Henan Province, 2020YB0146; Guangdong higher education reform project in 2020, No. 642, innovative research and practice of logistics personnel training mode based on new information technology under the background of new business. The project of quality engineering of Guangzhou College of Technology and Business in 2020, serial number 25, the exploration of the dynamic mechanism and path of the integration of production and education of undergraduate colleges in Guangdong-Hong Kong-Macao Greater Bay Area. Thanks for the help.

\section{References}

1. He Wuhua, Wang lingdun. Review and Prospect of curriculum ideological and political research in China [J]. School party construction and ideological education, 2021, (04): 26-30

2. Zhang Daliang. Curriculum, ideology and Politics: the fundamental principle of moral education in the new era $[\mathrm{J}]$. China higher education research, 2021, (01): 5-9

3. Fu Yong Xiang. "Internet plus" Ideological and political education helps foster [J]. youth forum for new era youth, 2021, (01): 94-96.

4. Liu Jianjun. Curriculum ideology and Politics: connotation, characteristics and path [J]. Education research, 2020,41 (09): 28-33

5. Zhang Jin. Innovating College Ideological and political education through "micro ideological and political" teaching mode $[\mathrm{J}]$. China higher education, 2020, (18): 27-29. 